\title{
Biologically Essential and Non-Essential Elements Causing Toxicity in Environment
}

\section{Swarn Lata Bansal ${ }^{1 *}$ and Sanjay Asthana²}

${ }^{1}$ Department of Chemistry, Lucknow University, Lucknow, Uttar Pradesh, India

${ }^{2}$ Department of Chemistry, DAV PG College, Kanpur, Uttar Pradesh, India

\begin{abstract}
This paper encompasses the toxicity of abundant and trace elements present on the earth. Generally, the less abundant elements are more toxic. But even the biologically essential elements become toxic above a critical concentration. The synergistic influence of a metal on toxicity of another is also discussed for mercury selenium and zinc-cadmium pairs. A general observation is made that for biologically important elements a single oxidation states are considerably more toxic. It is known that some elements viz., $\mathrm{C}, \mathrm{H}, \mathrm{O}, \mathrm{Na}, \mathrm{K}, \mathrm{N}, \mathrm{P}, \mathrm{S}, \mathrm{Mg}, \mathrm{Ca}, \mathrm{Cl}$ are major essentials for life and $\mathrm{B}, \mathrm{F}, \mathrm{Si}, \mathrm{V}, \mathrm{Cr}, \mathrm{Mn}, \mathrm{Fe}, \mathrm{Co}, \mathrm{Ni}, \mathrm{Cu}, \mathrm{Zn}, \mathrm{Se}, \mathrm{Mo}, \mathrm{Sn}$ and I are the trace elements essential for life. $\mathrm{Cr}$ (III) for example is essential for glucose and lipid metabolism, $\mathrm{Mn}(\mathrm{II})$ is a co-factor in a number of enzymatic reactions, $\mathrm{Fe}$ has major role in haemoglobin formation, $\mathrm{Co}(\mathrm{II})$ is a component of vit. $\mathrm{B} 12, \mathrm{NI}(\mathrm{II})$ has been found to be essential for mammals and $\mathrm{Mo}$ is an important co-factor for xanthine oxidase and aldehyde oxidase as a consequence of its different oxidation states. A minimum concentration of these elements is essential for proper growth of body, but beyond certain level of concentration these elements also become toxic. The threshold concentration is comparatively higher for the compounds of metals which have some biological function but for other metals ( $\mathrm{Pb}, \mathrm{Cd}, \mathrm{Hg}, \mathrm{As}, \mathrm{Sb}$ etc) the tolerance limit is very low. These metals get accumulated in body because they are not biodegradable.
\end{abstract}

Keywords: Essential elements; Trace element; Toxicity; Environment; Deficiency

\section{Introduction}

Essential elements participate in numerous biochemical vital processes necessary to maintain good health. Meanwhile, the majority of known metals and metalloids are very toxic to living organisms and even those considered as essential, can be toxic if present in excess. In last decades, the natural environment concentrations of several chemical elements (toxic and essential) have been largely increased, mostly as a result of anthropogenic activities [1-4]. They can impair important biochemical systems, constituting an important threat for the health of plants and animal systems. An overview of the environmental and biological fate of chemicals by living organisms is presented [57]. The industrial importance of many metals [8] concentration is increasing in atmosphere as they are released in the form of airborne particles and fumes (Figure 1). Cigarette smokers are inhaling $0.80 \mu \mathrm{g}$ of the highly toxic Cd per Cigarette pack and are also adding to the air pollution. The threshold limiting values for some common metals and their compounds are given in Table 1. Lethal dose values and attendant symptoms of toxic effects are also included in Table 1.

\section{Methods}

Concentrations of arsenic, chromium, cobalt, copper, lead, manganese, mercury, selenium and zinc were determined from environment. The validity of the methodology and the determination of its accuracy and precision were obtained from analytical procedure and analyzed. The results indicate reasonable agreement between the found and claimed values and good coefficient of variation (better or equal to 5\%). The Method Detection Limits were computed as three times the standard deviation of the digested blank samples and found to compare favourably with those reported in literature [9-12].

Among the highly toxic metals are beryllium, cadmium, lead, mercury and their compounds. Arsenic compounds in drinking water make users susceptible to skin cancer. Arsenic poison can be diagnosed by determining arsenic content of human hair and nail. Beef kidney eaters are ingesting cadmium from food and cigarette smokers through inhalation, which may cause protein urea. Atmospheric concentration of lead is also increasing due to continued consumption of gasoline containing lead alkyl additives.

The use of lead pipes carrying water supply results in increased intake of the metal. This metal accumulates in bones which contain $90 \%$ of total human body burden of lead. The WHO has permitted a maximum weekly intake of $0.5 \mathrm{mg} / \mathrm{kg}$ body weight of $\mathrm{Pb}$ in case of adults. This limit is much lower in case of infants and children as they are more prone to toxic effects. The use of copper in intrauterine devices is also not quite safe as this metal dissolving slowly at a rate of $25 \mu \mathrm{g}$ per day and hydroxyl radicals are formed which may cause potential problems [13-15].

The effects of exposure to elemental $\mathrm{Hg}$ vapour are highly species dependent and extrapolation of results on animals to human beings is not reasonable. $75 \%$ to $85 \%$ of inhaled vapour is absorbed and this portion may diffuse through alveolar membrane. Its oxidation occurs in blood. In case of long term exposures concentration of elemental Hg in brain may also increase and excretion being very slow, central nervous system may also be affected. Some microorganisms have a tendency to convert ionic mercury to short chain alkyl mercury compounds but warm blooded animals do not convert ionic mercury to alkyl mercury to any significant extent. Kidney is the main target of mercury toxicity. Inorganic $\mathrm{Hg}$ is accumulated in the kidney and it has been found that

${ }^{*}$ Corresponding author: Swarn Lata Bansal, Department of Chemistry, Lucknow University, Lucknow, Uttar Pradesh, India, Tel: 08808615285; E-mail: swtbansal28@gmail.com

Received February 21, 2018; Accepted March 15, 2018; Published March 18 2018

Citation: Bansal SL, Asthana S (2018) Biologically Essential and Non-Essential Elements Causing Toxicity in Environment. J Environ Anal Toxicol 8: 557. doi: 10.4172/2161-0525.1000557

Copyright: ( 2018 Bansal SL, et al. This is an open-access article distributed unde the terms of the Creative Commons Attribution License, which permits unrestricted use, distribution, and reproduction in any medium, provided the original author and source are credited. 
Citation: Bansal SL, Asthana S (2018) Biologically Essential and Non-Essential Elements Causing Toxicity in Environment. J Environ Anal Toxicol 8: 557. doi: 10.4172/2161-0525.1000557

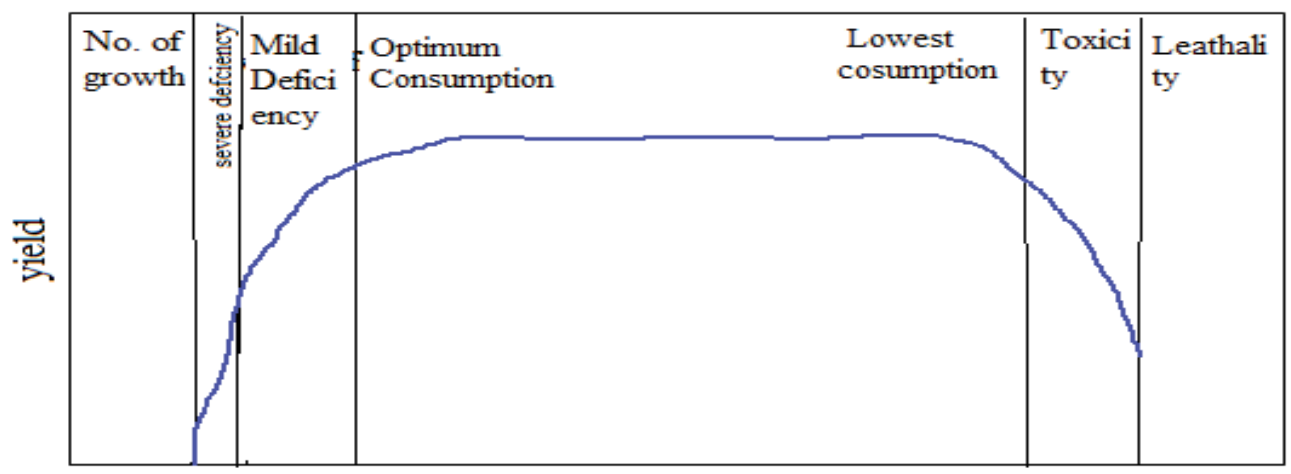

Nutrient Concentration

Figure 1: Nutrient Concentration

\begin{tabular}{|c|c|c|c|}
\hline Substances & $\begin{array}{c}\text { TLV } \\
\text { (in air) } \mathrm{mg} / \mathrm{m}\end{array}$ & $\begin{array}{c}\text { Degree of Toxicity /Lethal dose (in } \mathrm{mg} / \\
\mathrm{kg} \text { body } \mathrm{wt} \text { ) }\end{array}$ & Harmful Effects and Symptoms \\
\hline $\begin{array}{c}\text { Aluminium } \\
\mathrm{AlO}, \mathrm{Al}(\mathrm{SO}), \mathrm{AlF}, \mathrm{Al}(\mathrm{CH}), \mathrm{AlCl}\end{array}$ & 0.8 & $\begin{array}{r}700 \\
38\end{array}$ & Lung damage \\
\hline $\begin{array}{c}\text { Bismuth } \\
\mathrm{Bi}(\mathrm{NO}), \mathrm{BiOCl}\end{array}$ & 2.6 & Mild & Kidney damage \\
\hline $\begin{array}{c}\text { Boron } \\
\mathrm{H} \mathrm{BO}, \mathrm{B} \mathrm{H}, \mathrm{B} \mathrm{H}, \mathrm{B} \mathrm{H}\end{array}$ & 0.3 & 200 (adult) & Central nervous system \\
\hline $\begin{array}{c}\text { Chromium } \\
\text { Soluble Salts(dichromate) } \\
\text { Chromic acid }\end{array}$ & $\begin{array}{l}0.8 \\
0.2\end{array}$ & 60 & $\begin{array}{l}\text { Ulcertation of nose and skin, Lung } \\
\text { cancer } \mathrm{Cr}(\mathrm{VI})\end{array}$ \\
\hline $\begin{array}{l}\text { Cobalt } \\
\text { Coso }\end{array}$ & 0.7 & Mild & Lung damage and Goiter \\
\hline $\begin{array}{l}\text { Iron } \\
\text { Salts }\end{array}$ & 16.5 & Mild & Irritation in gastro- intestinal track \\
\hline $\begin{array}{l}\text { Manganese } \\
\mathrm{MnO}, \mathrm{KMnO}\end{array}$ & 2.0 & - & Paralysis of nervous system \\
\hline $\begin{array}{c}\text { Magnesium } \\
\text { MgO, } \\
\mathrm{MgF}, \mathrm{Mg}(\mathrm{CH} \mathrm{COO})\end{array}$ & 16.0 & $\begin{array}{l}250 \text { (acute) } \\
680 \text { ppm (inh.) } \\
10 \text { (acute) }\end{array}$ & $\begin{array}{l}\text { Tumours in wounds } \\
\text { Irritation in respiratory passage }\end{array}$ \\
\hline $\begin{array}{l}\text { Nickel } \\
\mathrm{Ni}(\mathrm{CO})\end{array}$ & $0.06 \mathrm{ppm}$ & 250 (inh.) & Dermatisis, Cancer, Lung damage \\
\hline $\begin{array}{l}\text { Osmium } \\
\text { OsO }\end{array}$ & 0.04 & 0.183 (inh.) & Eyes, respiratory passage \\
\hline $\begin{array}{c}\text { Phosphorous } \\
\text { Yellow phosphorous } \\
\text { H PO PCl } \\
\text { PCl PH } \\
\text { Platinum } \\
\text { (NH4)PtCl } \\
\text { Sod. Chloroplatinate }\end{array}$ & $\begin{array}{c}0.02 \\
1.0\end{array}$ & $\begin{array}{c}1.000 \text { (inh.) } \\
50 \mathrm{ppm} \text { for } 4 \mathrm{~h} \\
120 \mathrm{ppm} \text { (inh.) } \\
\text { 8ppm (inh.)for } 1 \mathrm{~h} \\
0.0009(\mathrm{H})\end{array}$ & $\begin{array}{l}\text { Bone injury and lung damage } \\
\text { Cancer }\end{array}$ \\
\hline $\begin{array}{l}\text { Selenium } \\
\text { SeO, } \\
\mathrm{HSe} \\
\mathrm{H} \mathrm{SeO} \\
\mathrm{SeF} \\
\mathrm{SeOCl} \\
\text { Selenates }\end{array}$ & 0.3 & $\begin{array}{c}4 \\
0.33 \text { (inh.) hor } 8 \mathrm{~h} \\
138 \\
10 \text { (inh.) } \\
0.9 \text { (dermal, H) } \\
25\end{array}$ & $\begin{array}{l}\text { Lung and liver damage } \\
\text { Garlic breath }\end{array}$ \\
\hline $\begin{array}{c}\text { Silver } \\
\text { AgNO } \\
\text { Colloidal Silver }\end{array}$ & & $\begin{array}{c}50 \\
100\end{array}$ & \\
\hline
\end{tabular}


Citation: Bansal SL, Asthana S (2018) Biologically Essential and Non-Essential Elements Causing Toxicity in Environment. J Environ Anal Toxicol 8: 557. doi: 10.4172/2161-0525.1000557

Page 3 of 5

\begin{tabular}{|c|c|c|c|}
\hline $\begin{array}{l}\text { Tellurium } \\
\text { TeF } \\
\text { TeO } \\
\text { TeF }\end{array}$ & 0.008 & $\begin{array}{c}5 \text { (dermal) } \\
324 \\
5 \text { ppm (inh.) }\end{array}$ & Unpleasant breath \\
\hline $\begin{array}{l}\text { Thallium } \\
\text { TI O } \\
\text { TISO } \\
\text { TI (SO) }\end{array}$ & & $\begin{array}{l}25 \\
23\end{array}$ & $\begin{array}{l}\text { Loss of hair, damage to nervous system } \\
\text { and Kidney }\end{array}$ \\
\hline $\begin{array}{c}\text { Tin } \\
\text { SnCl } \\
\text { Org. compds. }\end{array}$ & $\begin{array}{l}3.0 \\
2.0\end{array}$ & 800 & Skin \\
\hline $\begin{array}{c}\text { Titanium } \\
\mathrm{TiCl}\end{array}$ & - & 12 (inh.) for $2 \mathrm{~h}(\mathrm{H})$ & \\
\hline $\begin{array}{l}\text { Uranium } \\
\text { UO, UF }\end{array}$ & 0.07 & & Kidney damage, cancer \\
\hline $\begin{array}{l}\text { Vanadium } \\
\text { V O dust }\end{array}$ & 0.09 & 1.0 for $8 \mathrm{~h}(\mathrm{H})$ & Bronchitis and bronchopneumonia \\
\hline Fume & 0.08 & & \\
\hline $\begin{array}{c}\text { Zinc } \\
\mathrm{ZnO} \text {, dust }\end{array}$ & 7.0 & 5000 (inh), 1/2 h (H) & Fever \\
\hline
\end{tabular}

${ }^{*} T L V=$ Threshold limit value, MAC=Maximum acceptable concentration, $H=$ Human, $P=P i g$, inh.=inhalation, a=urine, $b=b l o o d, c-k i d n e y, d-l i v e r, e=b r a i n, ~ R=$ rat

Table 1: Toxicity of some common elements.

conversion of methyl mercury compounds to $\mathrm{Hg}(\mathrm{II})$ is slower than other alkyl or aryl $\mathrm{Hg}$ compounds. This may be the reason why methyl mercury compounds are more toxic than other organic mercury compounds.

\section{Results}

Analysis of results following an episode in which people living close to Minimata Bay in Japan were exposed to methyl mercury contamination showed that age, health and nutritional status are various factors which affect the total response to toxic effects. On most causes the maximum body burden is more important than the length of exposure. Methyl mercury, due to its lipid solubility, can penetrate the brain blood barrier and placental barrier and accumulate in tissues of the fetus, especially in brain, which causes mental deterioration and cerebral palsy. Hatchability of experimental hens fed with phenyl and methyl mercury compounds was found to be adversely effected but productivity of hens was found to be affected by methyl mercury compounds only. It has been shown that 2,3 di-phosphoglyceryl dehydrogenase combines with mercury, affecting the oxygen transport by haemoglobin and thus there may be a net haemoglobin increase in body of the exposed person. WHO has established a weekly intake to be $0.3 \mathrm{mg}$ mercury per person which may contain at the most 0.2 mg methyl mercury ion. A very significant investigation relates to the effect of selenium on the toxic effects of mercury. It was concluded that selenium counter acts the toxic effect of both organic and inorganic mercury compounds and so addition of selenium in diet may afford some protection against the toxic effects of methyl mercury. Table 2 summarises the current information relating to some toxic element.

The role of different oxidation states of transition metals which have some essential bio functions in the body and become toxic at a stage, but from the available data in Table 3, it can be seen that the oxidation states others than those required for vital metabolic processes are more toxic. This, however, may be an oversimplification. If we look at the concentrations of various metals in the earth's crust and sea water it turns out that the metals which are more abundant are less toxic. On the other hand, the more toxic metals are present in nature in considerably low concentrations. This may be the nature's way to preserve its own integrity.

\section{Discussion}

The general health of a person and the type of elements already present in the body are important factors in determining the toxic effect on the individual. Due to synergistic effects of metals on each other the toxic effects may reduce or enhance when present in combination. It has been found that $\mathrm{Zn}: \mathrm{Cd}$ ratio in body is of great importance in determining the effects of Zinc and Cadmium, "Garlic breath" is caused due to acute exposure to selenium compounds and dimethyl selenide is found to be presented in exhaled air. It has been found that arsenic, mercury and thallium inhibit the pulmonary excretion of dimethyl selenide but arsenic lowers the selenium concentration in tissues and minimises the liver damage. Copper has been found to antagonise the absorption of the more Mo(VI) compounds. Vanadium has been found to exert a synergistic effect on cadmium in causing heart diseases. The mechanism of toxic effect, the role of oxidation states involved in the disastrous action, the study of positive and negative effects of others metal ions present in the body are all vast fields open for research and exploration.

Recent studies have suggested that nutritional deficiencies in some essential elements may increase the toxicity of lead, and some essential elements may influence the blood concentrations of lead and other toxic metals. $\mathrm{Hg}, \mathrm{Pb}$, As are known for their toxicity, whereas $\mathrm{Mn}, \mathrm{Cu}, \mathrm{Zn}, \mathrm{Se}, \mathrm{Cr}$ (in the +3 state) and Co are essential elements. $\mathrm{Hg}$ is noted for its neurotoxicity and at high doses; it can cause serious damage to the central nervous system, brain and/or kidney. $\mathrm{Cu}, \mathrm{Zn}, \mathrm{Se}$, $\mathrm{Co}$, and $\mathrm{Cr}$ are important elements for human biological activities. $\mathrm{Cu}$ has been recognized as an essential element for many years because of its presence in important enzymes and proteins. $\mathrm{Cr}$ is also an essential nutrient required for sugar and fat metabolism. However, only scanty data are available on Co and Cr levels in worldwide.

\section{Conclusion}

In the light of above carefully carried out experimentation, it can be safely concluded that biologically essential elements show toxicity beyond a permissible concentration. Further it has also been evaluated that which particular oxidation state of different elements is more toxic than the other oxidation states. It can also be observed that although many metals have tremendous industrial importance, yet 
Citation: Bansal SL, Asthana S (2018) Biologically Essential and Non-Essential Elements Causing Toxicity in Environment. J Environ Anal Toxicol 8: 557. doi: 10.4172/2161-0525.1000557

Page 4 of 5

\begin{tabular}{|c|c|c|c|c|c|c|}
\hline Substances & $\mathrm{TLV} \mathrm{mg} / \mathrm{m}$ & $\begin{array}{l}\text { MAC in } \\
\text { body ppm. }\end{array}$ & $\begin{array}{l}\text { Lethal Dose mg/ } \\
\text { kg } \\
\text { Body wt. }\end{array}$ & $\begin{array}{l}\text { Industries where } \\
\text { used }\end{array}$ & Harmful Effects and symptoms & Reasons \\
\hline $\begin{array}{c}\text { Antimony } \\
\mathrm{SbCl}, \mathrm{Sb} \mathrm{S}, \mathrm{SbH}\end{array}$ & 0.7 & 2.0 & 100 & - & $\begin{array}{l}\text { Dermatitis, gastrointestinal disturbance, } \\
\text { injury to heart and kidney damage }\end{array}$ & - \\
\hline $\begin{array}{c}\text { Arsenic } \\
\text { AsO, } \mathrm{AH} \\
\text { AsCl, Arsenite }\end{array}$ & 0.35 & $\begin{array}{l}0.19 \\
2.0 \\
0.3\end{array}$ & $\begin{array}{c}120 \\
14\end{array}$ & Pesticides & $\begin{array}{l}\text { Dehydration, Diahorrea, loss of appetite, } \\
\text { dermatitis, loss of hair, white transverse } \\
\text { bands on nails }\end{array}$ & $\begin{array}{l}\text { Due to binding with } \\
\text { phosphase enzyme } \\
\text { reduces tissues respiration }\end{array}$ \\
\hline Cadmium & 0.08 & 0.20 & & $\begin{array}{l}\text { Ni-Cd Batteries, } \\
\text { galvanised water } \\
\text { pipes cigarette }\end{array}$ & $\begin{array}{l}\text { Pain and fracture of softened bones, } \\
\text { renal dysfunction, protein area, } \\
\text { emphysema (chronic cases) pulmonary } \\
\text { and cardio vascular system effected } \\
\text { (acute cases) }\end{array}$ & $\begin{array}{l}\text { Low intake of calcium and } \\
\text { cadmium exposure (lungs } \\
\text { and kidneys) }\end{array}$ \\
\hline $\begin{array}{l}\text { Lead } \\
\mathrm{PbO}, \mathrm{PbSO}\end{array}$ & & 0.10 & & $\begin{array}{l}\text { Combustion of } \\
\text { gasoline, water } \\
\text { pipes, antiknock }\end{array}$ & $\begin{array}{c}\text { Neurological } \\
\text { Problems, gastrointestinal disturbances }\end{array}$ & $\begin{array}{l}\text { Volatile org., compounds } \\
\text { penetrate through skin and } \\
\text { are absorbed in lungs and } \\
\text { gastrointestinal tract }\end{array}$ \\
\hline $\begin{array}{l}(\mathrm{CH} \mathrm{COO}) \mathrm{Pb} \\
(\mathrm{CH}) \mathrm{Pb} \\
(\mathrm{C} \mathrm{H}) \mathrm{Pb}\end{array}$ & $\begin{array}{l}0.12 \\
0.16 \\
0.10\end{array}$ & 0.5 & - & same & Anaemia & $\begin{array}{l}\text { Due to increased level of } \\
\text { ALA dehydrase in blood } \\
\text { and urine (accumulates } \\
\text { in bones, brain in case of } \\
\text { children) }\end{array}$ \\
\hline $\begin{array}{l}\text { Mercury } \\
\mathrm{HgCl}\end{array}$ & - & - & $28(\mathrm{H})$ & & $\begin{array}{l}\text { Loss of Side vision, nervous system } \\
\text { effected tremors inhands, difficulty in } \\
\text { understanding ordinary speech }\end{array}$ & $\begin{array}{l}\text { Coagulation, Irritation } \\
\text { and Superficial corrosion } \\
\text { of tissues, attaches to } \\
\text { sulfhydroxyl group and } \\
\text { inhibits enzyme system } \\
\text { such as phenol-sulfate } \\
\text { conjugation }\end{array}$ \\
\hline $\begin{array}{c}\mathrm{Hg}(\mathrm{CN})_{2} \\
\mathrm{HgSO}_{4} \\
\mathrm{Hg}\left(\mathrm{NO}_{3}\right)_{2} \\
\text { Elemental } \mathrm{Hg}\end{array}$ & $\begin{array}{l}0.8 \\
0.7\end{array}$ & $\begin{array}{c}(3-30) \\
(14-20)\end{array}$ & $\begin{array}{l}10(\mathrm{H}) \\
40(\mathrm{R}) \\
357(\mathrm{H}) \\
0.17 \text { (inh.) } \\
\text { For } 4 \text { yrs }\end{array}$ & $\begin{array}{l}\text { Furfelt industry } \\
\text { production of } \\
\text { chlorine, Sod. } \\
\text { Hydroxide, } \\
\text { thermometer etc. }\end{array}$ & Psychic and emotional disturbances & \\
\hline Aryl & 0.03 & $(4-10)$ & $30(\mathrm{R})$ & $\begin{array}{l}\text { Paper andPulp } \\
\text { industry }\end{array}$ & & \\
\hline Alkyl & & & $21(P)$ & $\begin{array}{l}\text { Fungicide and } \\
\text { seed dressing of } \\
\text { vegetables, e.g., } \\
\text { Soyabean, Sugar } \\
\text { beets }\end{array}$ & $\begin{array}{l}\text { Organic (Alkyl) } \\
\text { Tetratogenesis, fetus affected, central } \\
\text { nervous system, sore mouth, blisters on } \\
\text { skin, mental retardation(children) }\end{array}$ & $\begin{array}{l}\text { Irreversible loss of } \\
\text { special neurons } \\
\text { (accumulation in order } \\
\text { kidney>liver>blood >brain) }\end{array}$ \\
\hline
\end{tabular}

TLV=Threshold limit value, MAC=Maximum acceptable concentration, H=Human, $P=P i g$, inh.=inhalation, a=urine, $b=b l o o d, c-k i d n e y, ~ d-l i v e r, ~ e=b r a i n, ~ R=$ rat; Lethal $\mathrm{Dose}=(\mathrm{LD})=$ single dose necessary to kill $50 \%$ of a very large population under stated conditions. (values given are via oral route)Inhalation values are in ppm.

Table 2: Toxic effect of non-essential elements.

\begin{tabular}{|c|c|c|c|}
\hline $\begin{array}{l}\text { Elements and their common oxidation } \\
\text { states }\end{array}$ & $\begin{array}{c}\text { Stable oxidation state involved in } \\
\text { metabolism }\end{array}$ & Oxidation states with toxic effects & comments \\
\hline Vanadium (III and V) & III & $\mathrm{V}(\mathrm{V} \mathrm{O})$ & $\begin{array}{l}\text { Present in food, fats and oils from } \\
\text { combustion of fuel oils }\end{array}$ \\
\hline Chromium (II to VI) & III & VI Insoluble particulates & $\begin{array}{l}\text { Welding fumes from chromium bearing } \\
\text { alloys, carcinogenic }\end{array}$ \\
\hline Iron (II, III) & III & II & FeSO as oral iron preparation \\
\hline Molybdenum & - & VI & MoS, Non toxic \\
\hline Selenium (IV and VI) & Role not yet found & II and IV & $\mathrm{HSe}, \mathrm{SOCl}$ toxic \\
\hline Nickel (II, IV) & II & Zero & $\mathrm{Ni}(\mathrm{CO})$ from cigarette smokes \\
\hline Lead (II, IV) & II & IV & Toxic $\mathrm{Pb}(\mathrm{CH})$ \\
\hline Manganese (II, IV) & II & IV & MnO dust-central nervous system effected \\
\hline
\end{tabular}

Table 3: Oxidation state of elements involved in metabolism and principal oxidation states causing toxic effect. 
Citation: Bansal SL, Asthana S (2018) Biologically Essential and Non-Essential Elements Causing Toxicity in Environment. J Environ Anal Toxicol 8: 557. doi: 10.4172/2161-0525.1000557

Page 5 of 5

the use of these metals is causing an increase in their concentrations in environment and that is proving to be toxic to human beings. The role of different oxidation states of transition metals that are essential for various bio functions and their toxicity causing effects to human beings has also been established. Also, study has been carried out for the nutritional deficiencies of certain essential elements that influence the blood concentrations of some toxic metals. Similarly, Relation of certain essential elements to neurotoxicity has also been ascertained. The present study can be used for further correlating the concentrations of various elements and their effects on our ecosystem.

\section{References}

1. David G (2009) Methods of Biochemical analysis. Volume 19

2. Sax NI (1979) Dangerous Properties of Industrial Materials. Reinhold Pub Co., New York, NY, USA.

3. Nabawi A, Heinzow B, Kruse H (1987) Bulletin of Environmental Contamination and Toxicology 39: 889.

4. Andersen ME (1995) Development of physiologically based pharmacokinetic and physiologically based pharmacodynamic model for applications in toxicology and risk assessment. Toxicol Lett 79: 35-44

5. Barceloux DG (1999) Cobalt. Clinical Toxicology 37: 201-216.

6. Al-Yousuf MH, El-Shahawi MS, Al-Ghais SM (2000) Trace metals in liver, skin and muscle of Lethrinus lentjan fish species in relation to body length and sex.
Science of the Total Environment 256: 87-94

7. Andrej J, Stranai I, Kacaniova M, Massanyi P, Valent M (2006) Journal of Environmental Science and Health, Part A: Toxic/Hazardous Substances and Environmental Engineering 41: 1071.

8. Tulonen T, Pihlstrom M, Arvola L, Rask M (2006) Concentrations of heavy metals in food web components of small, boreal lakes. Boreal Environmental Research 11: 185.

9. Tuzen M (2009) Food and Chemical Toxicology 47: 1785.

10. Holmes P, James KA, Levy LS (2009) Is low-level environmental mercury exposure of concern to human health?. Science of the Total Environment 408: $171-182$.

11. Amirah MN, Afiza AS, Faizal WI, Nurliyana MH, Laili S (2013) Human health risk assessment of metal contamination through consumption of fish. J Environ Pollut Hum Health 1: 1-5.

12. Censi P, Spoto SE, Saiano F, Sprovieri M, Mazzola S, et al. (2006) Heavy metals in coastal water systems. A case study from the northwestern Gulf of Thailand. Chemosphere 64: 1167-1176.

13. ATSDR (Agency for Toxic Substances and Disease Registry) (2004) Evaluation of the toxicology of chemical mixtures commonly found at hazardous waste sites. Atlanta, GA, USA.

14. WHO (1996) Trace elements in human nutrition and health. World Health Organization, Geneva, p: 361.

15. WHO (2010) Exposure to Arsenic: A Major Public Health Concern. World Health Organization, Geneva. 